Supplement of The Cryosphere Discuss., 8, 6235-6250, 2014

http://www.the-cryosphere-discuss.net/8/6235/2014/

doi:10.5194/tcd-8-6235-2014-supplement

(C) Author(s) 2014. CC Attribution 3.0 License.

(c) (i)
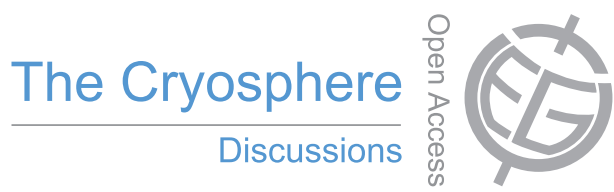

Supplement of

\title{
Brief Communication: 2014 velocity and flux for five major Greenland outlet glaciers using ImGRAFT and Landsat-8
}

A. Messerli et al.

Correspondence to: A. Messerli (messerli@nbi.ku.dk) 


\section{Supplementary material:}

All image dates used in this study. Note that red image pairs are included in the mean velocity field but not shown in the flow profiles in figure 2 .

Petermann:

24/08/2013-09/09/2013

29/09/2013-13/03/2014

$13 / 03 / 2014-12 / 04 / 2014$

24/03/2014-25/04/2014

$12 / 04 / 2014-25 / 05 / 2014$

$31 / 07 / 2014-18 / 09 / 2014$

31/07/2014-30/08/2014

Nioghalvfjerdsbræ:

22/03/2014-14/04/2014

27/05/2014-28/06/2014

28/06/2014-04/08/2014

28/06/2014-21/07/2014

21/07/2014-22/08/2014

04/08/2014-07/09/2014

Jakobshavn Isbræ:

09/02/2014-13/03/2014

13/03/2014-09/05/2014

09/05/2014-01/06/2014

01/06/2014-10/06/2014

08/06/2014-03/07/2014

03/07/2014-19/07/2014

$12 / 07 / 2014-11 / 08 / 2014$

11/08/2014-27/08/2014

01/06/2014-08/26/2014

03/07/2014-10/07/2014

03/07/2014-12/07/2014
Kangerdlugssuaq:

30/09/2013-08/11/2013

16/03/2014-03/05/2014

10/05/2014-11/06/2014

11/06/2014-13/07/2014

20/06/2014-22/07/2014

$22 / 07 / 2014-16 / 08 / 2014$

16/08/2014-17/09/2014

13/06/2014-13/07/2014

19/05/2014-20/06/2014

Helheim:

03/09/2013-21/11/2013

15/04/2014-01/05/2014

10/05/2014-11/06/2014

11/06/2014-13/07/2014

04/07/2014-29/07/2014

29/07/2014-21/08/2014

01/05/2014-10/05/2014

04/07/2014-13/07/2014 